\title{
Prognostic factors in acute mesenteric ischemia and evaluation with Mannheim Peritonitis Index and platelet-to-lymphocyte ratio
}

\author{
Eyüp Murat Yılmaz, M.D., Erdem Barış Cartı, M.D.
}

Department of General Surgery, Adnan Menderes University Faculty of Medicine, Aydın-Turkey

\begin{abstract}
BACKGROUND: Acute mesenteric ischemia (AMI) is a disease that has a very high mortality rate and for which the diagnosis is frequently delayed. The aim of the present study was to assess the predictive value of the Mannheim Peritonitis Index (MPI) and platelet-to-lymphocyte $(\mathrm{P} / \mathrm{L})$ ratio in the prognosis of $A M I$.
\end{abstract}

METHODS: The files of 34 patients diagnosed with AMI between September 2014 and April 2016 were retrospectively examined. The patients were divided into 2 groups based on survival. The parameters of MPI and P/L ratio, demographic data, and duration of hospitalization were recorded and compared.

RESULTS: In all, 19 (55.9\%) patients were male, and I5 (44.I\%) were female. Total of 19 patients (55.9\%) were discharged with a complete recovery, while 15 (44.1\%) died. MPI mean value was $21.13 \pm 7.55$ and $16.00 \pm 5.24$ in those who died and survived, respectively $(p=0.026)$. $P / L$ ratio was $288.48 \pm 233.01$ and $373.82 \pm 389.62$ in those who survived and died, respectively $(p=0.045)$.

CONCLUSION: MPI and P/L ratio are simple and reliable methods to predict the prognosis of AMI.

Keywords: Mannheim Peritonitis Index; mesenteric ischemia; platelet/lymphocyte ratio.

\section{INTRODUCTION}

Acute mesenteric ischemia (AMI) is a clinical condition with a mortality rate as high as $70 \%$, despite diagnosis and treatment. ${ }^{[I]}$ This condition is seen in $1 \%$ to $2 \%$ of patients admitted with abdominal pain, though it becomes more common with increasing age, and incidence may be up to $18 \%$ in individuals aged 65 years or more. ${ }^{[2]}$ The primary causes of such a high mortality rate are thought to be delayed diagnosis and various comorbid diseases seen in the elderly. While many blood analyses, such as lactate dehydrogenase, transaminases, D-dimer, D-lactate, and creatinine phosphokinase have been suggested for diagnosis of AMI, as yet, none is sufficiently specific or sensitive. ${ }^{[3]}$ Diagnosis can usually be made based

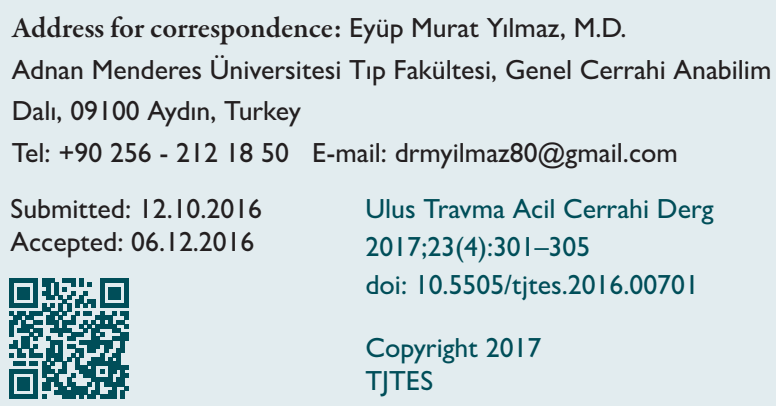

on computerized tomography (CT) and mesenteric $\mathrm{CT}$ angiography. ${ }^{[4]}$ However, the mortality rate remains high, despite surgical intervention following diagnosis. ${ }^{[1]}$

The Mannheim Peritonitis Index (MPI) is a special scoring system of parameters such as age; gender; duration, severity, and extent of peritonitis; presence of malignancy; and organ failure. ${ }^{[5-7]}$ Scoring systems such as the Peritonitis Index of Altona and the Acute Physiologic Assessment and Chronic Health Evaluation can also be used for peritonitis. ${ }^{[6,7]}$ Several studies have demonstrated the importance of these scoring systems in cases of peritonitis due to causes such as diverticulitis or colonic perforation. However, studies investigating the predictive value of these indices for peritonitis that develops due to conditions such as bacterial translocation, necrosis, or perforation in $\mathrm{AMI}$, are limited in the literature. ${ }^{[8]}$

The platelet-to-lymphocyte (P/L) ratio has been recognized in recent studies as a marker that, interestingly, can predict mortality in many inflammatory events, ranging from coronary artery disease to malignancy. ${ }^{[9,10]}$ While many studies have been conducted using the parameter of mean platelet volume (MPV) in AMI, the number of studies demonstrating the importance of $P / L$ as a marker in prognosis is very limited. However, these studies have reported that high $P / L$ value was associated with increased mortality. ${ }^{[10]}$ 
Table I. Mannheim Peritonitis Index

\begin{tabular}{lc}
\hline Risk factor & Weightage, if any \\
\hline Age $>50$ years & 5 \\
Female genders & 5 \\
Organ failures & 7 \\
Malignancy & 4 \\
Preoperative duration of peritonitis & 4 \\
$>24$ hours & \\
Origin of sepsis not colonic & 4 \\
Diffuse generalised peritonitis & 6 \\
Exudates & \\
Clear & 0 \\
Cloudy, purulent & 6 \\
Faecal & 12 \\
\hline
\end{tabular}

The aim of the present study was to investigate the predictive value of MPI together with $\mathrm{P} / \mathrm{L}$ ratio, a hematological marker, with respect to prognosis in patients with AMI.

\section{MATERIALS AND METHODS}

The files of patients with diagnosis of AMI who had been operated on by the general surgery clinic of Adnan Menderes University Faculty of Medicine between September 2014 and April 2016 were retrospectively investigated and included in this study. A review was performed using the MPI (Table I), and patients with missing data were excluded. The patients were divided into 2 groups: those who died and those who survived. Data regarding the duration of hospitalization, time from admission until operation, type of operation performed, and demographic details were recorded and statistically compared.

\section{Statistical Analysis}

Descriptive statistics of continuous variables are provided as mean $\pm S D$ and frequency (percent). The variables were assessed after prerequisites of normality and homogeneity of variance were evaluated (Shapiro-Wilk and Levene's tests). Independent t-test for 2 samples (Student's t-test) was performed, and Mann Whitney U-test was used when prerequisites were not met. For comparisons of 3 or more groups, one-way analysis of variance and the Tukey honest significant difference test were utilized. When the prerequisites were not met for those groups, Kruskal-Wallis test and Bonferroni-Dunn multiple comparison tests were used. The relationships between categorical variables were analyzed using Fisher's exact test and chi-square test. When the expected frequencies were less than $20 \%$, an assessment using the Monte Carlo simulation was performed to include these frequencies in the analysis. Significance level was expressed as $\alpha=0.05$ and $\alpha=0.0 \mathrm{I}$. Data were assessed using the SPSS Statistics for Windows, Version 17.0 (SPSS, Inc., Chicago, IL, USA) software package.

\section{RESULTS}

A total of 34 patients diagnosed with AMI were included in the study. Of those patients, 19 (55.9\%) were male, and 15 (44.1\%) were female. In all, 19 patients (55.9\%) were discharged with a complete recovery, while 15 (44.1\%) died.

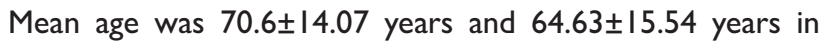

Table 2. Comparison of MPI and P/L ratios and durations

\begin{tabular}{|c|c|c|c|c|c|}
\hline Patients & $\mathbf{n}$ & Mean & Standard Deviation & Standard Error Mean & $\mathbf{p}$ \\
\hline \multicolumn{6}{|l|}{ Age } \\
\hline Survived & 19 & 64.63 & 15.54 & 3.56 & 0.255 \\
\hline Died & 15 & 70.60 & 14.07 & 3.63 & \\
\hline \multicolumn{6}{|c|}{ Mannheim score } \\
\hline Survived & 19 & 16.00 & 5.24 & 1.20 & $0.026^{*}$ \\
\hline Died & 15 & 21.13 & 7.55 & 1.95 & \\
\hline \multicolumn{6}{|l|}{$\mathrm{P} / \mathrm{L}$ ratio } \\
\hline Survived & 19 & 288.48 & 223.01 & 89.39 & $0.045^{*}$ \\
\hline Died & 15 & 373.82 & 389.02 & 57.58 & \\
\hline \multicolumn{6}{|c|}{ Time to laparotomy (hours) } \\
\hline Survived & 19 & 1.11 & 0.74 & 0.17 & 0.296 \\
\hline Died & 15 & 0.80 & 0.94 & 0.24 & \\
\hline \multicolumn{6}{|c|}{ Duration of hospitalization (days) } \\
\hline Survived & 19 & 11.05 & 10.03 & 2.30 & 0.43 \\
\hline Died & 15 & 8.40 & 9.05 & 2.34 & \\
\hline
\end{tabular}

${ }^{*} \mathrm{p}<0.05$. MPI: Mannheim peritonitis index; P/L: Platelet-to-lymphocyte. 
those who died and survived, respectively. Mean MPI value was $21.13 \pm 7.55$ and $16.00 \pm 5.24$ in those who died and survived, respectively $(p=0.026)$. $P / L$ ratio was $288.48 \pm 233.0$ I and $373.82 \pm 389.62$ in those who survived and died, respectively $(p=0.045)$. When the 2 groups were compared regarding length of time from admission to operation (hours) and duration of hospitalization (days), no statistically significant differences were found $(p=0.43)$ (Table 2).

Six $(17.6 \%)$ of the patients had undergone exploratory laparotomy and only I of them could be kept alive, with administration of anticoagulant therapy; in the remaining 5 cases, no intervention could be performed due to total small intestinal necrosis. Eleven (32.4\%) cases had undergone segmental small intestine resection and anastomosis, while 10 (29.4\%) cases had undergone segmental small intestine resection, but ileostomy was preferred in order to avoid risk to anastomosis. Two (5.9\%) patients had undergone subtotal small intestine resection, 2 (5.9\%) patients had undergone segmental small intestine resection and right colectomy, I (2.9\%) patient had undergone embolectomy, and 2 (5.9\%) had undergone other procedures. When the 2 groups (those who died and those who survived) were compared with respect to surgical intervention, a significant survival advantage was observed in the groups who had undergone segmental small intestine resection and segmental small intestine resection with ileostomy compared with other groups $(p=0.03)$ (Table 3$)$.

When the relationship of type of surgery and MPI score was analyzed, the exploratory laparotomy group had the highest score, while the embolectomy group had the lowest score $(p=0.00 \mathrm{I})$. Regarding P/L ratio, no statistically significant difference was found between groups based on surgical intervention $(p=0.594)$.

\section{DISCUSSION}

AMI is a condition characterized by intestinal infarction, and is more often seen in the elderly and those with atherosclerotic disease. ${ }^{[1]}$ It is not very common, but demonstrates significantly high mortality, and requires immediate diagnosis and therapeutic intervention. ${ }^{[1]}$ Early diagnosis is difficult; however, delayed diagnosis increases mortality. Therefore, several studies have been and are currently being conducted to better predict mortality and aid in prognosis for this condition.

Table 3. Surgical methods

\begin{tabular}{|c|c|c|c|c|c|}
\hline & & \multicolumn{2}{|c|}{ Died } & \multirow[t]{2}{*}{ Total } & \multirow[t]{2}{*}{$\mathbf{p}$} \\
\hline & & Survived & Died & & \\
\hline \multicolumn{6}{|l|}{ Gender } \\
\hline \multirow[t]{2}{*}{ Female } & $\mathrm{n}$ & 9 & 6 & 15 & 0.667 \\
\hline & $\%$ & 47.4 & 40.0 & 44.1 & \\
\hline \multirow[t]{2}{*}{ Male } & $\mathrm{n}$ & 10 & 9 & 19 & \\
\hline & $\%$ & 52.6 & 60.0 & 55.9 & \\
\hline \multicolumn{6}{|l|}{ Surgery } \\
\hline \multirow[t]{2}{*}{ Ex lap } & $\mathrm{n}$ & I & 5 & 6 & $0.03^{*}$ \\
\hline & $\%$ & 5.3 & 33.3 & 17.6 & \\
\hline \multirow[t]{2}{*}{ Segmental small intestine resection } & $\mathrm{n}$ & 8 & 3 & 11 & \\
\hline & $\%$ & 42.1 & 20.0 & 32.4 & \\
\hline \multirow[t]{2}{*}{ Embolectomy } & $\mathrm{n}$ & 0 & I & 1 & \\
\hline & $\%$ & 0.0 & 6.7 & 2.9 & \\
\hline \multirow[t]{2}{*}{ Subtotal small intestine resection } & $\mathrm{n}$ & I & I & 2 & \\
\hline & $\%$ & 5.3 & 6.7 & 5.9 & \\
\hline \multirow[t]{2}{*}{ Segmental small intestine resection + right colectomy } & $\mathrm{n}$ & I & I & 2 & \\
\hline & $\%$ & 5.3 & 6.7 & 5.9 & \\
\hline \multirow[t]{2}{*}{ Segmental small intestine resection + ileostomy } & $\mathrm{n}$ & 7 & 3 & 10 & \\
\hline & $\%$ & 36.8 & 20.0 & 29.4 & \\
\hline Other (Segmental small intestine resection and segmental small & $\mathrm{n}$ & I & 1 & 2 & \\
\hline intestine resection + ileostomy) & $\%$ & 5.3 & 6.7 & 5.9 & \\
\hline \multirow[t]{2}{*}{ Total } & $\mathrm{n}$ & 19 & 15 & 34 & \\
\hline & $\%$ & 100.0 & 100.0 & 100.0 & \\
\hline
\end{tabular}

$" p<0.05$. 
The MPI scoring system takes patient age, gender, presence of organ failure or malignancy, and parameters such as onset and extensiveness of peritonitis into consideration in determination of risk. ${ }^{[7]}$ Studies have generally estimated that in peritonitis case to which a score between 21 and 29 was assigned, the mortality rate would be as high as $65 \% .^{[12]}$ Some studies have predicted a mortality rate above $80 \%$ for peritonitis cases with MPI score above 29. ${ }^{[13]}$ In our study, mean MPI value was $16.00 \pm 5.24$ in those who survived, while value of $21.13 \pm 7.55$ was found in those who died, and the difference was statistically significant. Krylov et al. ${ }^{[14]}$ suggested in their study that mortality rate was lower and that a less radical surgical option may be appropriate in patient groups with $M P I$ value of $\leq 21$, while mortality rate was higher and radical surgery should be performed in groups with a value of $\geq 21$. Sharma et al. ${ }^{[15]}$ reported that MPI was a very good predictor of mortality and that its prognosis for patients with peritonitis could be relied upon. While there is a very limited number of studies evaluating the relationship between AMI and MPI, a study conducted by Yıldırım et al. ${ }^{[16]}$ of 46 patients with $A M I$ reported that patients with MPI of $\geq 26$ had a higher mortality rate, and that the use of this index on initial admission would contribute to prognosis. Since our study also found that patients with MPI value of $\geq 2$ I had a statistically significantly higher mortality rate, we recommend that this index be used during the initial admission evaluation of patients presenting to emergency departments with $\mathrm{AMI}$ and that it can be used reliably to estimate prognosis.

$P / L$ ratio has been studied in many inflammatory events, ranging from coronary artery disease to malignancies, and its value in prediction of prognosis has been well demonstrated. ${ }^{[9,10]}$ A study conducted by Kahramanca et al. ${ }^{[17]}$ reported that $\mathrm{P} / \mathrm{L}$ ratio was a good marker to estimate prognosis and debridement of Fournier's gangrene. It has also been shown to be an important marker for malignancy, and a study conducted by Stotz et al. ${ }^{[8]}$ reported that elevated $P / L$ value was a negative factor regarding curative resection in gastrointestinal stromal tumor. Since embolism and thrombosis associated with infarction are seen in AMI, it is thought that platelets might not be innocent within this pathogenetic process and studies have been conducted to investigate their potential role. ${ }^{[19]}$ Many studies have examined the association between MPV and mesenteric ischemia, and MPV has been reported to have value in the determination of prognosis. ${ }^{[20]}$ Studies of $P / L$ ratio, however, are limited in the literature. A study conducted by Toptas et al. ${ }^{[10]}$ reported that elevated $\mathrm{P} / \mathrm{L}$ ratio, along with elevated levels of other hematological markers, would be an important marker in the diagnosis of AMI, as well as prediction of prognosis and mortality. Our study results included a statistically significant difference in survival according to P/L ratio. Therefore, as in other inflammatory diseases, we suggest that a prognosis in AMI may be determined reliably with $\mathrm{P} / \mathrm{L}$ ratio, an inexpensive and simple test that can be analyzed within the scope of a hemogram.
Early diagnosis and appropriate treatment are important in AMI. ${ }^{[1]}$ Treatment options include methods ranging from radiological intervention to surgical methods. ${ }^{[2]}$ Early diagnosis and appropriate treatment intervention reduce mortality. Among surgical options used in the present study, the most preferred method was segmental small intestine resection. In approximately half of these cases, ileostomy was preferred, since we did not consider the anastomosis line to be safe. Embolectomy could be performed in only I case after the diagnosis had been made under appropriate conditions and at the proper time. When we compared the P/L ratio of cases, we found no statistical differences with respect to surgical method. Therefore, we think that this marker is important only in determining prognosis and does not contribute to the selection of surgical method or the subsequent process. Exploratory laparotomy cases had the highest MPI score, while the embolectomy case had the lowest, and this was statistically significant. In almost all of the exploratory laparotomy cases, the diagnosis was delayed, near total necrosis was observed during laparotomy, and the patients died before intervention could be performed. The embolectomy case, on the other hand, was a rare case in which early diagnosis and intervention were performed, and no peritonitis had developed. We think that the difference originates here, and therefore suggest that diagnosis be made as soon as possible, followed by the most appropriate intervention.

In conclusion, P/L ratio, which is reliable and simple to obtain, can be used together with MPI upon admission, and may help the surgeon and emergency physician predict prognosis in individuals thought to have AMI, an uncommon but highmortality disease.

No financial support was received for this study.

Conflict of interest: None declared.

\section{REFERENCES}

1. Karabulut K, Gül M, Dündar ZD, Cander B, Kurban S, Toy H. Diagnostic and prognostic value of procalcitonin and phosphorus in acute mesenteric ischemia. Ulus Travma Acil Cerrahi Derg 2011;17:193-8.

2. Akyüz M, Sözüer E, Akyıldız H, Akcan A, Küçük C, Poyrazoğlu B. Result of Surgical Therapy in Acute Mesenteric Ischemia. Kolon Rektum Hast Derg 2010;20:121-6.

3. Evennett NJ, Petrov MS, Mittal A, Windsor JA. Systematic review and pooled estimates for the diagnostic accuracy of serological markers for intestinal ischemia. World J Surg 2009;33:1374-83. [CrossRef]

4. Coskun AK, Halici Z, Oral A, Bayir Y, Deniz F, Cayc1 T, et al. The value of combined elevation of $\mathrm{D}$-dimer and neopterin as a predictive parameter for early stage acute mesenteric ischemia: An experimental study. Vascular 2016.

5. Sohn M, Agha A, Heitland W, Gundling F, Steiner P, Iesalnieks I. Damage control strategy for the treatment of perforated diverticulitis with generalized peritonitis. Tech Coloproctol 2016;20:577-83. [CrossRef]

6. Sökmen S, Çoker A, Ünek T, Tunçyürek P, Bora S. Peritonitli Hastalarda Mannheim Peritoin İndeksinin Etkinliği.Ulusal Travma Derg 
2001:100-3.

7. Malık AA, Wanı KA, Dar LA, Wanı MA, Wanı RA, Parray FQ. Mannheim Peritonitis Index and APACHE II - Prediction of outcome in patients with peritonitis. Ulus Travma Acil Cerrahi Derg 2010;16:2732.

8. Nachiappan M, Litake MM. Scoring Systems for Outcome Prediction of Patients with Perforation Peritonitis. J Clin Diagn Res 2016;10:1-5.

9. Kokcu A, Kurtoglu E, Celik H, Tosun M, Malatyalioglu E, Ozdemir AZ. May the platelet to lymphocyte ratio be a prognostic factor for epithelial ovarian cancer? Asian Pac J Cancer Prev 2014;15:9781-4. [CrossRef]

10. Toptas M, Akkoc İ, Savas Y, Uzman S, Toptas Y, Can MM. Novel hematologic inflammatory parameters to predict acute mesenteric ischemia. Blood Coagul Fibrinolysis 2016;27:127-30. [CrossRef]

11. Zhao Y, Yin H, Yao C, Deng J, Wang M, Li Z, et al. Management of Acute Mesenteric Ischemia: A Critical Review and Treatment Algorithm. Vasc Endovascular Surg 2016;50:183-92. [CrossRef]

12. Függer R, Rogy M, Herbst F, Schemper M, Schulz F. Validation study of the Mannheim Peritonitis. Chirurg 1988;59:598-601.

13. Notash AY, Salimi J, Rahimian H, Fesharaki MH, Abbasi A. Evaluation of Mannheim peritonitis index and multiple organ failure score in patients with peritonitis. Indian J Gastroenterol 2005;24:197-200

14. Krylov NN, Babkin OV, Babkin DO. Mannheim peritonitis index as a surgical criterion for perforative duodenal ulcer. Khirurgiia (Mosk) 2016;7:18-22. [CrossRef]

15. Sharma R, Ranjan V, Jain S, Joshi T, Tyagi A, Chaphekar R. A prospec- tive study evaluating utility of Mannheim peritonitis index in predicting prognosis of perforation peritonitis. J Nat Sci Biol Med 2015;6(Suppl 1):49-52. [CrossRef]

16. Yildırım D, Hut A, Tatar C, Dönmez T, Akıncı M, Toptaş M. Acute mesenteric ischemiade prognostik faktörler.Ulusal Cerrahi Derg 2016.

17. Kahramanca Ş, Kaya O, Özgehan G, İrkem B, Dural İ, Küçükpınar T, et al. Fournier gangreninde debridman sayısını öngörmede nötrofil lenfosit oranı ve trombosit lenfosit oranı Fournier gangreni şiddet indeksi kadar etkili midir? Ulus Travma Acil Cerrahi Derg 2014;20:107-12. [CrossRef]

18. Stotz M, Liegl-Atzwanger B, Posch F, Mrsic E, Thalhammer M, Stojakovic T, et al. Blood-Based Biomarkers Are Associated with Disease Recurrence and Survival in Gastrointestinal Stroma Tumor Patients after Surgical Resection. PLoS One. 2016;25:11. [CrossRef]

19. Budak YU, Polat M, Huysal K. The use of platelet indices, plateletcrit, mean platelet volume and platelet distribution width in emergency nontraumatic abdominal surgery: a systematic review. Biochem Med ( $\mathrm{Za}$ greb) 2016;26:178-93. [CrossRef]

20. Türkoğlu A, Gül M, Oğuz A, Bozdağ Z, Ülger BV, Yılmaz A, et al. Mean platelet volume: is it a predictive parameter in diagnosis of acute mesenteric ischemia? Int Surg 2015;100:962-5. [CrossRef]

21. Alemanno G, Somigli R, Prosperi P, Bergamini C, Maltinti G, Giordano A, et al. Combination of diagnostic laparoscopy and intraoperative indocyanine green fluorescence angiography for the early detection of intestinal ischemia not detectable at CT scan. Int J Surg Case Rep 2016;26:7780. [CrossRef]

\section{ORIJINAL ÇALIŞMA - ÖZET}

\section{Akut mezenter iskemide prognostik faktörler ve Mannheim peritonit indeksi ve trombosit/lenfosit oranı ile değerlendirilmesi \\ Dr. Eyüp Murat Yılmaz, Dr. Erdem Barış Cartı \\ Adnan Menderes Üniversitesi Tıp Fakültesi, Genel Cerrahi Anabilim Dalı, Aydın}

AMAÇ: Akut mezenter iskemi (AMi), tanısı geç konan ve mortalitesi oldukça yüksek bir hastalıktır. Mannheim peritonit indeksi (MPi) ve trombosit/ lenfosit (T/L) oranının akut mezenter iskeminin prognozu üzerine etkisini araştırmak.

GEREÇ VE YÖNTEM: Akut mezenter iskemi tanısı konan 34 hastanın dosyaları, Eylül 20।4-Nisan 2016 tarihleri arasında geriye dönük olarak tarandı. Hastalar hayatını kaybeden ve kaybetmeyen diye iki gruba ayrıldı. Hastaların MPi ve T/L oranları, demografik verileri, yatış süreleri kaydedilip karşılaştırıldı.

BULGULAR: Hastaların 19'u erkek (\%55.9), I5'i kadın (\%44. I) olarak saptandı. Toplam I5 hasta hayatını kaybederken (\%44. I), I9 hasta (\%55.9) sağlıklı taburcu edildi. Mannheim periton indekslerine bakıldığında ise hayatını kaybeden hastalarda ortalama değer 21 .। $3 \pm 7.55$ bulunurken, hayatını kaybetmeyen hastalarda 16.00 \pm 5.24 olarak saptandı $(p=0.026)$. Trombosit/lenfosit oranlarına bakıldığnda hayatını kaybetmeyen grupta $288.48 \pm 233.0$ I saptanırken hayatını kaybeden grupta ise $373.82 \pm 389.62$ olarak bulundu $(p=0.045)$.

TARTIŞMA: Akut mezenter iskemi tablosunda, prognozu ön görmede MPI ve T/L oranları basit ve güvenilir yöntemlerdir.

Anahtar sözcükler: Mannheim peritonit indeksi; mezenter iskemi; trombosit/lenfosit oranı.

Ulus Travma Acil Cerrahi Derg 2017;23(4):30I-305 doi: 10.5505/tjtes.2016.0070I 